\section{The Royal College of Psychiatrists' Winter Business Meeting 2008}

25 January 2008, 12.30 p.m., to be held at the Royal College of Psychiatrists following the meeting of the Central Executive Committee. Chaired by the President, Professor Sheila Hollins.

\section{Agenda}

1. To approve the Minutes of the previous Winter Business Meeting held at the Royal College of Psychiatrists on 23 January 2007.

2. Obituary

3. Election of Honorary Fellows

\section{The Right Honorable} Baroness Murphy of

\section{Aldgate}

By any standards Elaine Murphy has had an outstanding career. Never afraid of controversy, her contributions have been innovative and inspirational to a generation of young doctors. As a prominent media campaigner for people with dementia and their carers she did much to draw attention to their hardship.

When appointed the first Chair of Geriatric Psychiatry in the UK she was the first woman and youngest person appointed to a Chair at Guys' and St Thomas' Hospital.

During a distinguished academic career, when she was founding editor of what was to become the leading international journal of geriatric psychiatry, she was a Personal Advisor to the Chief Medical Officer and UK Advisor to the World Health Organization's European Region on older people and mental health. Later she became Vice Chair of the Mental Health Act Commission. She has held several positions in NHS management, including Chair of North East London Strategic Health Authority.

In 2004 she was appointed a life peer and has continued to fight causes of health and social care, including the Mental Capacity Bill and the Mental Health Act Amendment Bill. She is secretary to the All Party Parliamentary Groups on dementia and mental health.

It is time that the College recognised her enormous contribution, in so many spheres of public and professional life, to improving the care of people with mental illness.

\section{DrAdam Roger Mark Freeman}

In addition to 27 years as a general adult psychiatrist, Roger has made a significant contribution in three areas.

First was his local and regional advisory and managerial work. Four years as Chair of the North West Psychiatric Regional Advisory Committee and five years as a Divisional Director of Mental Health within acute and mental health trusts are not unusual appointments. Thirteen years as Clinical Director of Mental Health Services in Hillingdon, despite numerous reorganisations, shows not only considerable commitment but also the value placed on his work.

Second is Roger's commitment to the College. He was secretary to and then Chair of the Parliamentary Liaison Committee for 21 years and a member of the Public Policy Committee for 23 years. It can be seen that his mere 8 years as a member of Council and 4 years as Chair of the Chiltern and Thames Valley Division of the College are barely worth mentioning. Since January 2007 he has been one of the two members appointed as Scrutineer of Elections.

Third, and most importantly, is the extraordinary time and commitment he has made to trying to ensure that the needs of our patients and colleagues are understood by parliamentarians. His tireless and unstinting work in relation to specific pieces of legislation has been invaluable (for example his work for the College and the Mental Health Alliance in relation to the Mental Health Bill). More fundamentally, Roger established the modus operandi of the College's interface with Parliament, through involvement with the All Party Parliamentary Groups, attendance at Party Conferences and other contacts. It is no exaggeration to say that he became the 'face of the College' to MPs and Peers. It is important for us to recognise that our achievements in relation to legislative and other parliamentary matters are a direct result of the relationships he has had made and College practices he has put into place, which underpinned all of our work with Parliament. To give an idea of the scale of the work this is an example of the Bills dealt with over the 2-year period 20022004: Assisted Dying Bill 2004, Children Bill 2004, Community Care (Delayed Discharges) Bill 2003, Criminal Justice Bill 2003, Disability Discrimination Bill 2004, Domestic Violence, Crime and Victims Bill 2004, Draft Mental Health Bill 2002, Draft Mental Incapacity Bill 2003, Gambling Bill 2004, Gender Recognition Bill 2004, Human Tissues Bill 2004, Mental Capacity Bill 2004, Sexual Offences Bill 2003.

\section{Dr Steven Sharfstein}

Steven S. Sharfstein is President and Chief Executive Officer of Sheppard Pratt Health System in the USA, where he has worked for 21 years. He is also Clinical Professor and Vice Chair of Psychiatry at the University of Maryland. A practising clinician for more than 30 years, he is best known for his research and writing on the economics of practice and public mental health policy.

Over a period of 13 years, he held a variety of positions at the US National Institute of Mental Health, including Director of Mental Health Service Programs, as well as positions in consultation/liaison psychiatry and research in behavioural medicine on the campus of the National Institutes of Health. He has written on a wide variety of clinical and economic topics and has published more than 140 professional papers, 40 book chapters and 10 books, including (as co author) Madness and Government: Who Cares for the Mentally III?, a history of the federal Community Mental Health Centres Program.

A graduate of Dartmouth College and the Albert Einstein College of Medicine, Dr Sharfstein trained in psychiatry at the Massachusetts Mental Health Center in Boston from 1969 to 1972 . He also received a Masters in Public Administration from the Kennedy School of Government in 1973 and a certificate from the Advanced Management Program at the Harvard Business School in 1991. He was Secretary of the American Psychiatric Association from 1991 to 1995, its Vice President from 2002 to 2004 and President from 2005 to 2006. Dr Sharfstein also received the Human Rights Award from the American Psychiatric Association in 2007.

\section{Professor Jonathan Paul Shepherd}

With increasing availability of alcohol, its consumption is reaching crisis proportions in the UK, especially among young people. Jonathan Shepherd is remarkable for having made a difference in improving safety in this field, and also for inspiring and sustaining energy and enthusiasm in others for the continuing struggle both for primary prevention of excessive alcohol use and for prevention of harm from the violence that often accompanies it. As a maxillofacial surgeon working with serious injuries, he recognised opportunities not only to heal physical wounds but also to ease some of the mental trauma associated with a violent episode. He set in train a range of strategies to reduce risk of further harm where 
possible, and its extent where not. His work is evidence based, much of the evidence accrued through his own tremendous capacity for converting observation into hypothesis and then funded, relevant research. He follows through with accurate and practical messages conveyed with formidable clarity to all levels of local and national government.

His work has already had significant impact on public safety through environmental improvements such as changes in the type of glass used in public houses and closure of certain roads during peak drinking hours. More individually targeted interventions have stemmed from his strong and productive relationships with psychiatrists. He has implemented strategies for early engagement in counselling about substance use and/or timely engagement in therapy for traumatic stress, as appropriate - seizing the opportunity offered during recovery from surgery to start such therapeutic work with many people who would otherwise bypass such help. He has also worked closely with victims' organisations, and was national Vice Chair of the charity Victim Support in 2001-2004. A great multidisciplinary worker, he has long advocated closer academic working with police, and has been instrumental in establishing the first university-based police school, in Cardiff, in 2006

Jonathan Shepherd's publications reflect the diversity and quality of his academic work, and the extent of his interdisciplinary collaborations, within and outside the health service. Too many to list individually, they number over 160 peerreviewed data-based papers alone, and in addition many editorials, reviews, chapters and countless influential letters in high-impact surgical, dental, general medical, psychiatric, addictions, public health, criminological, police and victimology journals and books, as well as the wider press, including The Times and The Times Higher Education Supplement. He played a key role in setting up a national database of injury management in accident and emergency departments that yields a more accurate picture of the epidemiology of serious community violence than any other system.

Professor Shepherd has already been widely honoured in the UK and overseas, the listings below reflecting only the major awards and titles. He continues to be in much demand by national government bodies and by international bodies such as the World Health Organization.

His national and international contributions to personal and community safety have not distracted him from more conventional clinical academic achievements, which have also been substantial. $\mathrm{He}$ is Professor of Oral and Maxillofacial Surgery, Director of the Violence Research Group and Vice Dean of the Dental School at Cardiff University.

\section{DrAnthony Stephen Zigmond}

Rarely can the fortunes of an area of psychiatric practice have rested so completely and so securely on the shoulders of one man as has mental health legislation on those of Tony Zigmond. From the moment the government decided to reform the current Mental Health Act and to introduce a Mental Capacity Act, Tony has worked tirelessly to ensure that their proposals should be fair to patients and feasible for their carers.

As Vice-President of the College from 2003 to 2005 and Honorary VicePresident thereafter, Tony has been the voice of the College within the Mental Health Alliance, within all aspects of the media and within the Houses of Parliament itself. He has given countless unofficial 'tutorials' to parliamentary Members, given formal evidence to many Joint and Select Committees, and been cited in their reports and subsequent debates more often than anyone except Ministers themselves. It is no exaggeration to say that the best bits of legislation could not have been achieved, and the worst bits avoided, without the skill and sensitivity of Tony and the relation he struck up with parliamentarians who so came to rely on him.

In the process, Tony withstood what was sometimes bitter personal attack to raise the profile of the College and to earn it immense respect within Parliament, public groups and other professional and voluntary groups. Most importantly, anyone with a mental illness that might be subject to mental health legislation owes him an enormous debt of gratitude. It is difficult to think of anyone who more deserves this award. Typically, Tony himself is modest about his achievement, preferring to put others forward while he continues to work as a busy consultant in Leeds, as a Mental Health Act Commissioner for over a decade, and as a trainer everywhere, helping to implement the practice of which he has been such an eloquent and passionate architect.

doi: 10.1192/pb.bp.107.018846 